
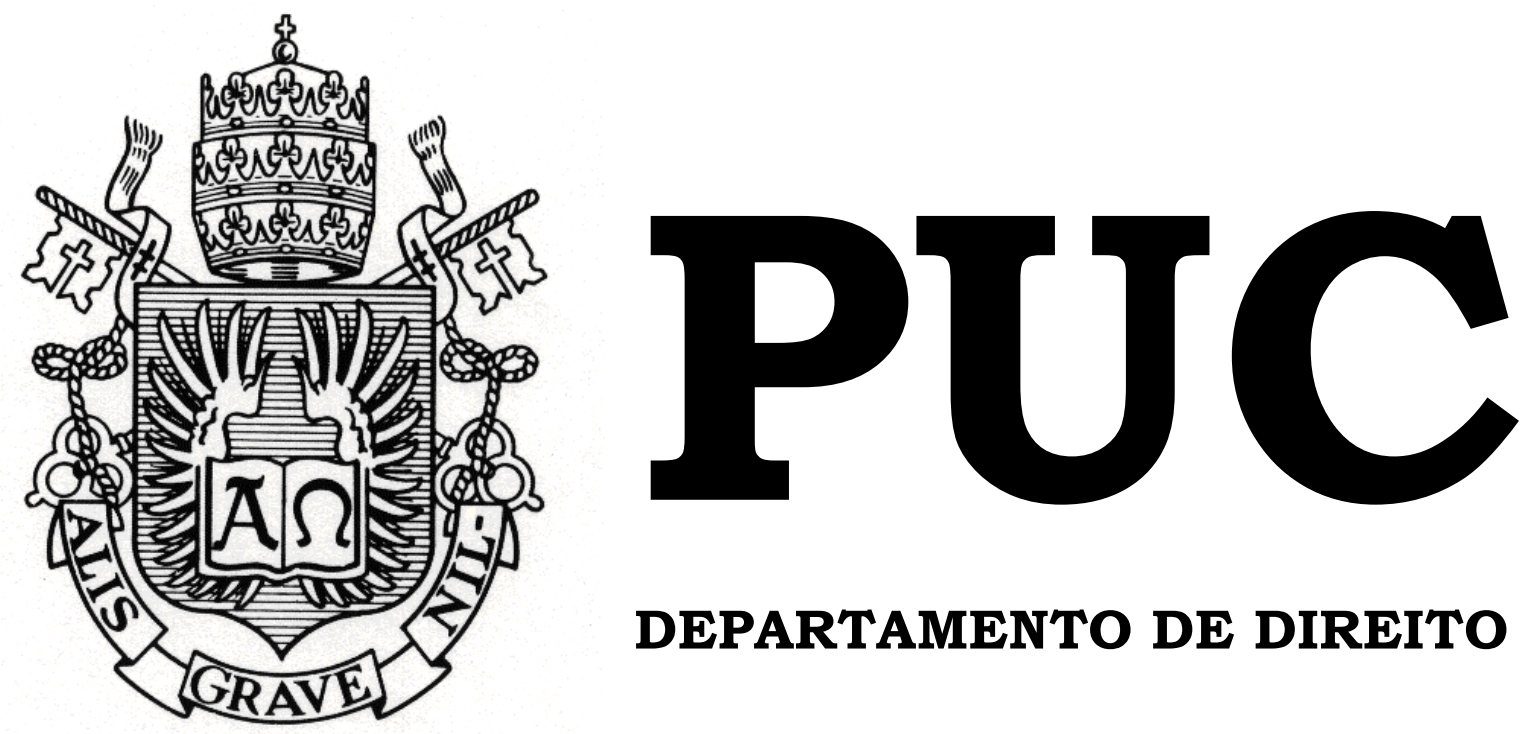

DEPARTAMENTO DE DIREITO

\title{
CLÁUSULA COMPROMISSÓRIA DE ARBITRAGEM EM ESTATUTO SOCIAL DE SOCIEDADE ANÔNIMA
}

por

FÁBIO WERNECK DE MENDONÇA

ORIENTADOR: LAURO GAMA JR.

2011.1

PONTIFÍCIA UNIVERSIDADE CATÓLICA DO RIO DEJANEIRO

RUA MARQUÊS DE SÃO VICENTE, 225 - CEP 22453-900

RIO DE JANEIRO - BRASIL 


\title{
CLÁUSULA COMPROMISSÓRIA DE ARBITRAGEM EM ESTATUTO SOCIAL DE SOCIEDADE ANÔNIMA
}

\author{
por \\ FÁBIO WERNECK DE MENDONÇA
}

Monografia Apresentada ao Departamento de Direito da Pontifícia Universidade Católica do Rio de Janeiro (PUC-Rio) para a obtenção do Título de Bacharel em Direito.

Orientador: Lauro Gama Junior 
Aos meus pais, Por todas as sábias escolhas, A minha avó, Pela presença constante em minha vida, Ao meu irmão, Pelo companheirismo inigualável, Ao meu afilhado, Por ser a mais nova felicidade em minha vida. 


\section{AGRADECIMENTOS}

Chegou a hora de entregar a monografia e me formar na faculdade de Direito da Pontifícia Universidade Católica do Rio de Janeiro. Cinco anos fantásticos que passaram voando, e que me trouxeram amigos, conhecimentos e aprendizados que vou levar para sempre comigo.

Este momento é um verdadeiro marco na minha vida acadêmica e profissional, e posso falar que é uma pura mistura de sensações. É excelente e eu estou muito feliz, pois chegou a hora de ser advogado e viver os desafios de uma nova etapa da vida. É triste, porque os melhores anos da minha vida vão ficar para trás.

Eu não chegaria até aqui se não fossem todas as pessoas que me apoiaram ao longo destes vários anos de colégio e faculdade. A começar por meus pais, que tomaram uma das decisões mais importantes da minha vida no ano de 1994, quando me matricularam no Colégio de São Bento. Bato no peito com orgulho para falar que sou beneditino e que concluí integralmente o curso neste colégio. A excelente educação e meus bons e velhos amigos de CSB constituíram o passo mais importante da minha vida rumo ao sucesso.

Quero agradecer a toda minha família, que são as pessoas mais importantes da minha vida. Meus pais, meus padrinhos, minha avó, meu irmão e todos os tios e primos! E especialmente ao meu afilhado Gabriel. Amo vocês, obrigado por estarem sempre por perto.

Os anos de PUC-Rio foram realmente mágicos. Ingressei na graduação em 2006 para cursar Direito. Não sabia o que esperar, pois fui uma espécie de aventureiro da família, o primeiro a desbravar o mundo jurídico. Conheci, nos primeiros períodos da faculdade, os amigos que estão até hoje e estarão para sempre ao meu lado: Bezão Doutel, Fefê Moura, 
João Marçal, Bruno Barreto, Josef Azulay, Ana Luiza Mello, Didi Carneiro, Pé Grande, Hugo Wery e Renan Vieira.

Ao longo dos anos a PUC-Rio me proporcionou experiências cada vez melhores, dentre as quais gostaria de destacar algumas. A participação no CAEL - Centro Acadêmico Eduardo Lustosa, incluindo a vitória histórica do Contracorrente nas eleições, me aproximou de pessoas com os mais belos ideais do Direito. Posso citar aqui Doutel, Fabrício, Cristiano e Mansur como os responsáveis por me fazer participar deste movimento.

"Jamaaaaaaais" esquecerei dos jogos jurídicos, choppadas, pires, e festas juninas! Conheci pessoas incríveis com quem divido sempre esses momentos. Bibi, Patê, Alana e Bia não me deixam mentir!

Comecei a estagiar na metade da faculdade, e só tenho a agradecer a todas as pessoas com que trabalhei no Andrade \& Fichtner Advogados, Basílio Advogados, IBAM e OGX Petróleo e Gás. Estive sempre rodeado de pessoas inteligentes e competentes que em muito contribuíram para minha formação. Sem contar as grandes amizades que fiz em todos estes lugares! Obrigado de coração!

Um agradecimento especial aos meus amigos do GEADICI - Grupo de Estudos em Arbitragem e Direito do Comércio Internacional da PUCRio, do qual tive o orgulho de fazer parte juntamente com as pessoas mais inteligentes que conheci na faculdade. Obrigado ao prof. Lauro Gama, que além de me ajudar nesta monografia também coordenou com paixão as atividades do grupo. A participação no 18th Willem C. Vis International Commercial Arbitration Moot em Viena foi uma experiência que não posso medir em palavras! Obrigado pela ajuda, convívio e inspiração de todos vocês, grandes amigos! Rumo ao título em 2012, vamos trazer o caneco para a PUC-Rio! 
Gostaria de poder listar todos os meus amigos, pois todos eles são muito importantes em minha vida. Mas Pedro Werneck, Marcella Libardoni, Gabriel Tabachi, Tom Rache, Francisco Figueira e Maria Vitória foram importantes em muitos destes momentos!

Agora, às vésperas de me formar, eu não poderia estar mais satisfeito, pois sou um apaixonado pelo Direito e não me vejo trabalhando em outra área. Espero estar pronto para os novos desafios da vida da advocacia. Bring it on! 
"Do what thou wilt shall be the whole of the Law"

"Faze o que tu queres

há de ser o todo da Lei"

(Aleister Crowley) 


\section{RESUMO}

Trata-se de trabalho monográfico com o objetivo de refletir sobre os efeitos decorrentes da inserção de cláusula compromissória de arbitragem em estatuto social de uma sociedade anônima. Primeiramente será analisada a possibilidade de que as controvérsias e disputas societárias sejam resolvidas através de arbitragem e como isto constitui uma garantia constitucional do acesso à justiça. No capítulo seguinte, passaremos à análise dos limites subjetivos dos efeitos decorrentes desta inserção, levando em consideração o momento em que o acionista ingressou na companhia e a sua manifestação de vontade em relação à cláusula compromissória estatutária. Tal análise será feita através da ponderação dos princípios da autonomia da vontade e do princípio da maioria, que são, respectivamente, os princípios basilares da arbitragem e das sociedades anônimas. Após apresentar as posições doutrinárias divergentes e as nossas conclusões sobre quais acionistas estão vinculados à arbitragem, passaremos à análise dos efeitos e limites objetivos da cláusula arbitral, refletindo sobre questões polêmicas e sobre quais conflitos relacionados às sociedades e seus acionistas são passíveis de análise e deliberação pelo juízo arbitral, assim como problemas decorrentes dos efeitos intertemporais da cláusula. Por último, levando em conta as posições doutrinárias e os princípios jurídicos analisados,

analisaremos a cláusula arbitral do regulamento do Novo Mercado da BM\&F Bovespa.

\section{PALAVRAS - CHAVE}

Arbitragem - Sociedades Anônimas - Princípio da Autonomia da Vontade

- Princípio da Maioria - Acesso à justiça - Limites Subjetivos e Objetivos da Cláusula Arbitral 


\section{SUMÁRIO}

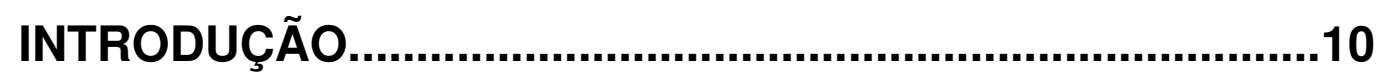

\section{CAPÍTULO 1 - A ARBITRABILIDADE DAS}

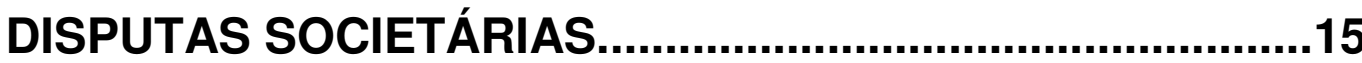

1.1 A possibilidade de submeter disputas

societárias à arbitragem

1.2 A Constitucionalidade da Arbitragem

e a Garantia do Acesso a Justiça.

\section{CAPÍTULO 2 - OS LIMITES SUBJETIVOS DA CLÁUSULA COMPROMISSÓRIA DE ARBITRAGEM EM ESTATUTOS} SOCIAIS.

2.1.1 $\mathrm{O}$ acionista fundador da sociedade.

2.1.2 O acionista que votou a favor da inserção da cláusula arbitral. 23

2.1.3 O acionista que ingressou na companhia após a inserção da cláusula arbitral.

2.1.4 $\mathrm{O}$ acionista ausente ou que se absteve de votar na assembleia.

2.1.5 O acionista que dissentiu da inserção da cláusula arbitral.

2.1.6 O acionista sem direito a voto ou com voto restrito

\section{CAPÍTULO 3 - OS LIMITES OBJETIVOS DA CLÁUSULA COMPROMISSÓRIA DE ARBITRAGEM EM ESTATUTOS SOCIAIS}

3.1 A Arbitragem Envolvendo Direitos

Políticos do Acionista

3.2 A Questão das Nulidades. .40 


\subsection{Aplicação da Cláusula Compromissória}

CAPÍTULO 4 - A CLÁUSULA ARBITRAL DO REGULAMENTO DO NOVO MERCADO DA BM\&F BOVESPA.

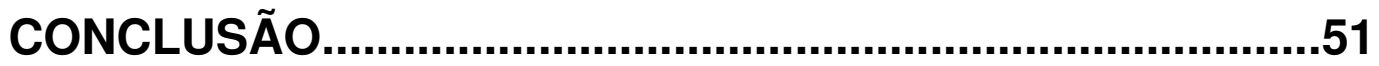

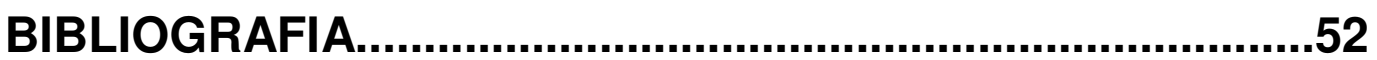




\section{INTRODUÇÃO}

O objetivo desta monografia é refletir sobre as questões controversas relacionadas à prática da Arbitragem, mais especificamente no âmbito das Sociedades Anônimas e do Mercado de Capitais.

Primeiramente será feito um breve histórico da evolução do instituto da arbitragem no Brasil, esclarecendo sua importância na atualidade, para então apontar os motivos e razões que me levaram a ter interesse pelo tema e a escrever o presente trabalho monográfico.

A arbitragem como método de resolução de disputas é um instituto tão antigo que antecede a própria existência do Estado Democrático de Direito e de suas instituições. Entre os povos antigos, quando não existiam juízes estatais, a arbitragem e a mediação constituíam meio comum para sanar os conflitos entre as pessoas.

No Brasil, a previsão legal da arbitragem como método de resolução de disputas existe desde a época do Brasil Colônia. As Ordenações Filipinas ${ }^{1}$, a Constituição de $1824^{2}$, o Código Comercial de $1859^{3}$, o Código Civil de $1916^{4}$ e o Código de Processo Civil de $1939^{5}$ são alguns dos diplomas legais que previam a arbitragem como método para resolução de conflitos. O Código Comercial previa, inclusive, a arbitragem

\footnotetext{
${ }^{1}$ As Ordenações Filipinas disciplinavam a arbitragem no Livro III, Título XVI - Dos juízes árbitros.

${ }^{2}$ Constituição de 1824, Art. 160. "Nas civeis, e nas penaes civilmente intentadas, poderão as Partes nomear Juizes Arbitros. Suas Sentenças serão executadas sem recurso, se assim o convencionarem as mesmas Partes."

${ }^{3}$ Código Comercial de 1850. Art. 294: "Todas as questões sociais que se suscitarem entre sócios durante a existência da sociedade ou companhia, sua liquidação ou partilha, serão decididas em juízo arbitral.";

Art. 245: "Todas as questões que resultarem de contratos de locação mercantil serão decididas em juízo arbitral.”; Art. 302: "A escritura, ou seja pública ou particular, deve conter: (...) 5 - A forma da nomeação dos árbitros para juízes das dúvidas sociais."

${ }^{4}$ Código Civil, de 1916 Art. 1.037: "As pessoa capazes de contratar poderão, em qualquer tempo, louvar-se, mediante compromisso escrito, em arbitros, que lhes resolvam as pendencias judiciais, ou extrajudiciais."

${ }^{5}$ Código Processual Civil de 1939 - Livro IX - Do Juízo Arbitral."
} 
obrigatória, ao dispor que determinadas questões "serão decididas em juízo arbitral”. Apesar da previsão legal, a arbitragem no Brasil sempre foi caracterizada pelo desuso, devido a diversos fatores, dentre os quais podemos destacar o da necessidade de homologação da sentença arbitral pelo Poder Judiciário. ${ }^{6}$

A arbitragem foi finalmente contemplada por lei específica em 1996, com o advento da Lei $\mathrm{n}^{\circ} 9.307^{7}$, que reformou completamente o instituto. A Lei prevê, em seu art. $1^{\circ}$, que poderão ser resolvidos por arbitragem os conflitos relativos a direitos patrimoniais disponíveis ${ }^{8}$, conceito este que engloba desde disputas contratuais entre empresas ou particulares, mas também, e é este o tema que será objeto de análise nesta monografia, disputas envolvendo acionistas e a companhia ou entre os acionistas controladores e os acionistas minoritários.

A Lei de Arbitragem inovou no ordenamento jurídico brasileiro, prevendo inovações eficazes como a execução compulsória da cláusula $\operatorname{arbitral}^{9}$, sem necessidade da posterior celebração de compromisso arbitral ${ }^{10}$ e a dispensa da homologação da decisão do árbitro por juiz togado, previsões estas até então inexistentes no Brasil. Ou seja, a cláusula compromissória de arbitragem passou a ter plena eficácia e a sentença arbitral condenatória passou a ser considerada título executivo judicial. ${ }^{11}$

\footnotetext{
${ }^{6}$ Art. 1098 a 1102, CPC, Lei 5.869/1973, revogados pela Lei 9.307/1996.

${ }^{7}$ Disponível em: http://www.planalto.gov.br/ccivil/leis/L9307.htm

${ }^{8}$ Lei $9.307 / 1996$, Art. $1^{\text {o. }}$ " As pessoas capazes de contratar poderão valer-se da arbitragem para dirimir litígios relativos a direitos patrimoniais disponíveis."

${ }^{9}$ Lei 9.307/1996, Art. 4: “A cláusula compromissória é a convenção através da qual as partes em um contrato comprometem-se a submeter à arbitragem os litígios que possam vir a surgir, relativamente a tal contrato;

${ }^{10}$ Art. 6º , Parágrafo único: "Não comparecendo a parte convocada ou, comparecendo, recusar-se a firmar o compromisso arbitral, poderá a outra parte propor a demanda de que trata 0 art. $7^{\circ}$ desta Lei, perante o órgão do Poder Judiciário a que, originariamente, tocaria o julgamento da causa."

${ }^{11}$ Lei 9.307/1996, Art. 31: “A sentença arbitral produz, entre as partes e seus sucessores, os mesmos efeitos da sentença proferida pelos órgãos do Poder Judiciário e, sendo condenatória, constitui título executivo."
} 
Houve, na época da promulgação da Lei de Arbitragem, bastante controvérsia doutrinária quanto à constitucionalidade destes dispositivos, o que só foi pacificado em 2001, com o julgamento do Agravo Regimental em Sentença Estrangeira 5.206-7 pelo Supremo Tribunal Federal, que declarou a constitucionalidade da Lei de Arbitragem ${ }^{12}$.

A partir desta decisão o instituto adquiriu força e passou finalmente a ter seu uso disseminado no Brasil. A arbitragem se tornou eficiente pois passou a oferecer inúmeras vantagens em relação ao processo judicial, dentre os quais podemos destacar os da celeridade e flexibilização do procedimento, o da especialização e possibilidade de escolha dos árbitros, a redução dos gastos e melhor utilização dos recursos financeiros e a confidencialidade dos procedimentos.

A importância da arbitragem no mundo globalizado, onde o número e o dinamismo das transações comerciais crescem e evoluem em uma progressão vertiginosa, é inquestionável. Desta forma, é necessário que os conflitos originados destas relações sejam solucionados em tempo hábil e de maneira eficiente, condizente com o dinamismo das atividades realizadas. Como consequiência, é notável a preferência das empresas, pela resolução de seus conflitos através da arbitragem ${ }^{13}$.

O meu interesse em particular pelo tema surgiu quando ingressei no GEADICI - Grupo de Estudos em Arbitragem e Direito do Comércio Internacional da PUC-Rio. Dentre os diversos temas estudados neste

\footnotetext{
${ }^{12}$ Agravo Regimental em Sentença Estrangeira 5.206-7. Conforme o voto proferido pelo Min. Nelson Jobim no Agravo Regimental em Sentença Estrangeira n. 5.206-7, são constitucionais o parágrafo único do art. $6^{\circ}$, o art. $7^{\circ}$ e os arts. 41 a 44 da Lei n. 9.307/96. Em sentido contrário, o voto do Min. Sepúlveda Pertence, que entendeu inconstitucionais os referidos dispositivos. Votaram ainda pela constitucionalidade os Mins. Ilmar Galvão, Ellen Gracie, Maurício Corrêa, Marco Aurélio, Celso de Mello e Carlos Velloso. Pela incostitucionalidade votaram também os Mins. Moreira Alves, Sydney Sanches e Néri da Silveira.

${ }^{13}$ Conforme pesquisa da PricewaterhouseCoopers, $73 \%$ das empresas preferem adotar a arbitragem como método de resolução de disputas. Disponível em: http://qmul.academia.edu/LoukasMistelis/Papers/207135/PricewaterhouseCoopers_International_ Arbitration_Corporate_Attitudes_and_Practices. Acesso em 13 de Maio, 2011.
} 
verdadeiro grupo de excelência, o que mais despertou meu interesse foi este que trata dos efeitos decorrentes da inserção de cláusula compromissória de arbitragem em estatuto social de uma sociedade anônima e, por esta razão, o escolhi para refletir, tratar e desenvolver neste trabalho monográfico.

O estudo da arbitragem em conflitos societários é de extrema importância, pois as diversas controvérsias características deste tema são objeto de divergências entre renomados doutrinadores, possuindo todos os temas tratados ampla aplicação prática. É necessário buscar uma solução uniforme para estas controvérsias, de modo a evitar a ocorrência de nulidades no processo arbitral, o que causaria atrasos nos procedimentos, acarretando grande perda de tempo e dinheiro, causando problemas indesejáveis no funcionamento das Sociedades Anônimas e conseqüiente prejuízo para os acionistas.

As controvérsias analisados pela doutrina sobre este tema envolvem desde a possibilidade da arbitrabilidade das questões societárias, passando pela análise dos efeitos subjetivos da inserção da cláusula compromissória estatutária, que consiste em analisar quais acionistas da companhia estão vinculados ao pacto arbitral. O alcance dos efeitos objetivos da cláusula também é objeto de discussão, para que se delimite as questões societárias que poderão ser efetivamente decididas por arbitragem e o momento a partir do qual a cláusula arbitral opera seus efeitos.

Outro tópico interessante, mas que não será desenvolvido neste trabalho sob pena de se fazer uma análise superficial dos demais assuntos, é a questão da contraposição entre a confidencialidade dos procedimentos arbitrais com o dever de full disclosure, ou seja, o dever de transparência das sociedades anônimas, principalmente no que diz respeito à suas 
demonstrações financeiras, que foi reforçado no Brasil pela Instrução Normativa n. 58 da CVM, publicada em 2002. ${ }^{14}$

A linha de pesquisa em que se insere este trabalho tem como objetivo principal, portanto, identificar, analisar e compreender os efeitos subjetivos e os alcances objetivos da inserção da cláusula de arbitragem em estatuto social de uma sociedade anônima para, ao final, concluir sobre quais acionistas estão efetivamente vinculados à cláusula compromissória estatutária.

\footnotetext{
${ }^{14}$ Disponível em: http://www.cvm.gov.br/asp/cvmwww/atos/Atos_Redir.asp?Tipo=I\&File=/inst/inst058.doc. Acesso em 12 de maio de 2011.
} 


\section{Capítulo 1 \\ A Arbitrabilidade das Disputas Societárias}

\subsection{A Possibilidade de Submeter Disputas Societárias à Arbitragem}

A Lei de Arbitragem, ao alterar substancialmente o tratamento dispensado à arbitragem no direito brasileiro, trouxe diversas vantagens que efetivamente transformaram-na em um método eficaz de solução de litígios. Segundo disposição da nova Lei, em se tratando de direitos sobre os quais as partes possam dispor, poderão elas também eleger o método para a resolução do conflito envolvendo estes direitos.

A Lei, não fez menção expressa sobre a possibilidade de submeter disputas societárias à arbitragem, mas toda e qualquer controvérsia sobre a possibilidade da utilização da arbitragem como método de resolução de conflitos de interesses no âmbito societário foi definitivamente pacificada com a reforma da Lei das Sociedades Anônimas trazida pela Lei 10.303/2001. Com a inclusão do par. $3^{\circ}$ no art. $109^{15}$, passou a ser expressa a previsão de que as divergências entre os acionistas ou entre acionistas e companhia poderão ser dirimidas através de arbitragem.

Marcelo Bertoldi entende que a estipulação de cláusula compromissória estatutária já era possível antes da reforma operada em 2001, e que a intenção do legislador com esta reforma foi realçar ainda mais a possibilidade de utilização deste instrumento de solução de litígios. ${ }^{16}$

As sociedades passaram a adotar a arbitragem em seus estatutos principalmente pelo fato das dificuldades incorridas pelo Poder Judiciário

\footnotetext{
15 Art. 109, § 3으: "O estatuto da sociedade pode estabelecer que as divergências entre os acionistas e a companhia, ou entre os acionistas controladores e os acionistas minoritários, poderão ser solucionadas mediante arbitragem, nos termos em que especificar".

${ }^{16}$ BERTOLDI, Marcelo et al.. Reforma da Lei das Sociedades Anônimas - Comentários à lei 10.303, de 31.10.2001. São Paulo: RT, 2002. 67 p.
} 
para dirimir as complexas divergências surgidas no âmbito das intrincadas relações entre os acionistas e a companhia. Este fato é decorrente da lamentável morosidade da justiça brasileira, causado devido ao excesso de demandas, e pela falta de especialização dos juízes, salvo raras exceções, para julgar as matérias de maior complexidade envolvendo questões societárias.

A própria Bolsa de Valores de São Paulo - BM\&F Bovespa estimula a adoção da arbitragem, sendo este um requisito obrigatório para que a companhia seja listada no nível mais elevado de governança corporativa, denominado Novo Mercado. A BM\&F Bovespa criou, inclusive, a Câmara de Arbitragem do Mercado, que pode ser eleita para dirimir disputas societárias e do mercado de capitais de qualquer interessado, investidor ou empresa, que seja ou não uma companhia aberta. Analisaremos, no Capítulo 4 desta obra, os efeitos subjetivos decorrentes da alteração da redação da cláusula arbitral constante no regulamento do Novo Mercado da BM\&F Bovespa. ${ }^{17}$

Ao adotar a cláusula arbitral em seu estatuto social, a companhia deve atentar para determinadas características próprias da cláusula compromissória estatutária, que deverá conter a indicação da câmara arbitral escolhida, ser explícita quanto às partes e suas relações societárias, bem como sobre os limites da competência arbitral. Neste sentido, Modesto Carvalhosa e Nelson Eizirik:

"é prudente que a entidade arbitral seja desde logo indicada na cláusula arbitral estatutária para o efeito de tornar indiscutível a sua competência, na conformidade preestabelecida das suas regras e regulamentos, que regerão, portanto, o processamento da arbitragem". ${ }^{18}$

\footnotetext{
${ }^{17}$ Mais informações disponíveis em: http://www.camaradomercado.com.br/

${ }^{18}$ CARVALHOSA, Modesto e EIZIRIK, Nelson. A Nova Lei das S/A. São Paulo: Saraiva, 2002. $187 \mathrm{p}$.
} 
A cláusula arbitral estatutária possui certos limites de abrangência, que serão objeto de análise neste trabalho. As grandes controvérsias discutidas em sede doutrinária sobre o tema dizem respeito às questões relacionadas aos limites subjetivos e objetivos da cláusula arbitral. Ou seja, é aceito, devido à previsão legal, que a arbitragem pode ser usada para dirimir conflitos societários, porém se discute quem são os acionistas que estão vinculadas à cláusula compromissória inserida no estatuto social, bem como quais questões poderão ser submetidas ao juízo arbitral.

\subsection{A Constitucionalidade da Arbitragem e a Garantia do Acesso à Justiça}

Constitui a arbitragem um instrumento eficaz de acesso à justiça ou a possibilidade de sua eleição advém justamente da renúncia a este direito constitucional? Esta controvérsia decorre da interpretação do art. $5^{\circ}, \mathrm{XXXV}$ da Constituição Federal, que dispões que "a lei não excluirá da apreciação do Poder Judiciário lesão ou ameaça a direito”.

Parte da doutrina considera a arbitragem uma garantia do acesso à justiça que, desta maneira, cumpre estritamente com a garantia constitucional. Neste sentido, Pedro Batista Martins assevera:

\footnotetext{
"afora as conhecidas vantagens - celeridade, informalidade e confidencialidade que o processo arbitral costuma proporcionar, cremos que, numa visão macro, essa importante via de solução das controvérsias desempenha papel relevante e primordial como instrumento eficaz de acesso à justiça." ${ }^{19}$ (grifos nossos)
}

Sustentando uma posição contrária, o comercialista Modesto Carvalhosa entende que a submissão a um juízo arbitral advém justamente da renúncia a um direito essencial do pactuante que, ao celebrar o compromisso arbitral, estaria renunciado à garantia constitucional do acesso

\footnotetext{
${ }^{19}$ MARTINS, Pedro Antonio Batista. Aspectos Fundamentais da Lei de Arbitragem. Rio de Janeiro: Forense, 1999. 1 p.
} 
à justiça. ${ }^{20}$ Devido à natureza facultativa da cláusula compromissória, o estatuto não poderia, de maneira alguma, privar os acionistas do acesso à justiça. Esta privação, segundo Carvalhosa, ocorreria nos casos de obrigatória vinculação do acionista que nunca acordou em submeter suas disputas com a companhia ou com o acionista majoritário à arbitragem. Afirma o doutrinador que a vinculação à arbitragem constituiria um óbice à justiça para o acionista minoritário que não anuiu aos termos da cláusula compromissória.

Para entendermos a questão, devemos buscar a ratio do supramencionado artigo da Constituição Federal. Quando da sua elaboração, a intenção por trás da redação do artigo era criar uma garantia para por fim à arbitrariedade dos processos administrativos e inquéritos policiais, atribuindo ao Poder Judiciário o controle da legalidade dos atos do Executivo e do Legislativo, em defesa dos direitos individuas. O comando constitucional é endereçado aos governantes, mais especificamente ao legislador, pois expressamente diz que é a lei que não que não excluirá da apreciação do Poder Judiciário lesão ou ameaça a direito. Este artigo de modo algum foi inserido na Constituição para limitar o poder de contratar das pessoas. ${ }^{21}$

Este entendimento foi brilhantemente desenvolvido pela Ministra Ellen Gracie, em seu voto no Agravo Regimental na Sentença Estrangeira n. 5.206-7/2001, que declarou a constitucionalidade da Lei de Arbitragem:

\footnotetext{
"A leitura que faço da garantia enfocada no art. $5^{\circ}, \mathrm{XXXV}$, é de que a inserção da cláusula assecuratória de acesso ao judiciário, em nosso ordenamento constitucional, tem origem e se explica pela necessidade de precatarem-se os direitos dos cidadãos contra a atuação de órgãos administrativos, próprios de regimes autoritários. A arqueologia da garantida da via judiciária leva-nos a verificar que a cláusula sempre teve em mira, preponderantemente, o direito de

${ }^{20}$ CARVALHOSA, Modesto e EIZIRIK, Nelson. Op. cit. p. 180.

${ }^{21}$ MAGAlHÃES, Rodrigo Almeida. A Constitucionalidade da Arbitragem. Disponível em http://direito.newtonpaiva.br/revistadireito/docs/prof/13_prof_rodrigo5.pdf. Acesso em 10 de maio de 2011.
} 
defesa ante os tribunais, contra atos dos poderes públicos. Por isso mesmo é, iniludivelmente, o legislador o destinatário da norma" (grifos nossos).

A conclusão, portanto, é de que é a lei, e não o poder de contratar dos particulares, que não pode excluir da apreciação do Poder Judiciário lesão ou ameaça a direito.

A finalidade da previsão constitucional é buscar, em ultima instância, a justiça, materializada através da prestação da tutela jurisdicional. Pedro Batista Martins acentua que no Brasil sempre imperou uma cultura paternalista, na qual apenas o Estado, através de seus órgãos jurisdicionais, teria legitimidade para resolver qualquer espécie de conflito. Porém, esta tradição é contestada pelo questionamento: "qual a valia de preceitos constitucionais assecuratórios de direitos e garantias se o caminho-meio inviabiliza o fim almejado pela sociedade?" 22 No Brasil, a prestação da tutela pelo Judiciário tem sido, de certa maneira, negado à população. Os Tribunais recebem milhares de processos todos os meses, levando assim com que cada lide leve no mínimo alguns anos para ser solucionada.

Podemos concordar que o papel do Estado é assegurar os direitos do cidadão. No momento em que o Poder Judiciário não consegue cumprir com estas obrigações, se faz necessária a busca por métodos alternativos de resolução de disputas. Este é um dos contextos que proporciona o sucesso da arbitragem, que deve ser promovida pelo Estado como método legítimo e eficaz de resolução de disputas. $\mathrm{O}$ interesse em submeter as disputas à arbitragem não é apenas das partes contratantes, mas também do Estado, já que "os meios alternativos de solução de conflitos coadunam-se com o interesse do Estado em ter pacificado o animo social."

\footnotetext{
${ }^{22}$ MARTINS, Pedro Antonio Batista. Op. cit. p. 3 e 8.

${ }^{23}$ Ibid. p. 7.
} 
A questão ainda é mais delicada no âmbito das sociedades anônimas, que são, em geral, empresas dotadas de grande dinamismo e envolvidas em diversas relações comerciais. Nesta seara, a arbitragem aparece muitas vezes como único método eficaz para dirimir os conflitos, devido a celeridade dos procedimentos e do alto grau de especialidade dos árbitros.

Caso se recorra ao Judiciário para buscar, por exemplo, a anulação de determinado ato do acionista controlador, por considerá-lo abusivo, corre-se o risco de ter que esperar anos até que o juiz profira a sentença. Com o decorrer do tempo, a tutela pretendida pode se tornar totalmente ineficaz, seja pela perda do objeto, seja pelo fato de que uma eventual decisão não produza mais o efeito pretendido. Neste caso não se estará cumprindo com o direito constitucional do acesso a justiça.

A celeridade do procedimento é apenas um dos benefícios da arbitragem no âmbito das sociedades anônimas. A especialidade dos árbitros que julgam as causas é uma característica ainda mais importante, pois, nas palavras de Modesto Carvalhosa e Nelson Eizirik, ela "promove melhor a distribuição da justiça em decorrência da presteza e aprofundamento técnico que a sentença arbitral pode trazer às partes que a convencionaram”. 24.

Por estas razões é que ousamos discordar do entendimento de Modesto Carvalhosa e nos filiar à posição defendida por Pedro Batista Martins, já analisada, que coaduna-se com a posição de José Eduardo Carreira Alvim, para quem a adoção da arbitragem trata-se, na verdade, de negócio jurídico processual, se opondo assim à posição conservadora, pois:

"tanto não se trata de renúncia ou de uma revogação da jurisdição que não pode ser declarada de ofício pelo juiz (ope legis), dependendo, necessariamente, de alegação da parte (ope exceptionis). Ademais, se de renúncia ou de revogação se

\footnotetext{
${ }^{24}$ CARVALHOSA, Modesto e EIZIRIK, Nelson. Op. cit. p.180.
} 
tratasse, não poderiam as partes recuperá-la, caso a arbitragem não chegasse a um bom termo, pois não se readquire aquilo a que se renuncia ou revoga." 25

Nestes termos concluímos que o direito das partes de optarem pela arbitragem advém do próprio exercício do direito de acesso à justiça. A arbitragem existe para garantir a plenitude da realização deste direito.

${ }^{25}$ ALVIM, José Eduardo Carreira. Tratado Geral de Arbitragem. Belo Horizonte: Mandamentos, 2000. 144-145 p. 


\section{Capítulo 2 \\ Os Limites Subjetivos da Cláusula Compromissória de Arbitragem em Estatutos Sociais}

\subsubsection{O acionista fundador da sociedade}

É pacífico na doutrina que os acionistas que participam da constituição da sociedade e, ao elaborar o estatuto social, optam pela inclusão da cláusula arbitral estatutária estão, para todos os efeitos legais, vinculados à ela. Todos os fundadores estão vinculados a cada uma das disposições do estatuto social, sendo desnecessária qualquer formalidade adicional para promover a validade e eficácia das mesmas, pois, neste caso, podemos presumir que todas as disposições estatutárias foram discutidas e aprovadas pelos fundadores.

Inclusive Modesto Carvalhosa e Nelson Eizirik, mais conservadores, adotam este entendimento, nos seguintes termos:

\footnotetext{
"No momento da constituição da sociedade, estarão vinculados à cláusula compromissória todos os fundadores que subscreveram o capital social. São eles que fundam a sociedade e aprovam o seu estatuto. Pode-se dizer, portanto que os fundadores-subscritores da sociedade não aderem ao estatuto, mas efetivamente o aprovam." 26
}

Os fundadores da companhia estão vinculados a cada uma das disposições estatutárias, após a sua aprovação por assembleia ou por subscrição particular. Não pode se cogitar a aplicação, neste caso, do art. $4^{\circ}$, par. $2^{\circ}$ da Lei de Arbitragem, em uma eventual analogia com os contratos de adesão, para requerer o consentimento dos acionistas fundadores em documento apartado e por escrito, pois foram os próprios fundadores da companhia que tomaram a iniciativa de inserir a cláusula compromissória no estatuto, tornando assim desnecessária qualquer formalidade adicional para torná-la eficaz.

\footnotetext{
${ }^{26}$ CARVALHOSA, Modesto e EIZIRIK, Nelson. Op. cit. p. 191.
} 


\subsubsection{O acionista que votou a favor da inserção da cláusula}

Caso a cláusula compromissória não tenha sido incluída quando da constituição da sociedade, será possível a sua inclusão através de reforma do estatuto social. Podem se extrair dois efeitos da manifestação de vontade dos acionistas quanto à esta deliberação: (i) a vontade de submissão do próprio do acionista; e (ii) a vontade de submissão da companhia ao juízo arbitral. Os acionistas, ao mesmo tempo em que exprimem coletivamente a vontade compromissória da sociedade, exprimem também a sua própria vontade compromissória individual.

Quando da aprovação da reforma do estatuto, não restam dúvidas de que a sociedade estará vinculada, na forma do par. $3^{\circ}$, art. 109, da Lei das S.A., aos termos da cláusula compromissória, justamente porque a sua vontade é exprimida através da vontade da maioria, e estará sempre refletida nos termos do estatuto social.

Modesto Carvalhosa e Nelson Eizirik comentam estes dois efeitos da manifestação de vontade única:

\footnotetext{
"Em primeiro lugar a sociedade é parte vinculada à cláusula compromissória, ao declarar o seu estatuto que as controvérsias surgidas entre a sociedade e seus acionistas serão deferidas à decisão do juízo arbitral. Dessa forma, a norma estatutária constitui em si mesma a cláusula compromissória que vincula, de um lado, a sociedade e, de outro, aqueles acionistas que manifestaram duplamente essa vontade, pela sociedade e por si mesmos" 27
}

Também estão vinculados à arbitragem todos os acionistas que votaram a favor e aprovaram a inserção da cláusula compromissória no estatuto social da companhia. A vontade do acionista de se submeter à arbitragem é extraída justamente de seu voto neste sentido na assembleia geral que deliberou sobre a reforma do estatuto para inserção da cláusula.

\footnotetext{
${ }^{27}$ CARVALHOSA, Modesto e EIZIRIK, Nelson. Op. cit. p. 194.
} 
Não há controvérsias doutrinárias para este caso específico dos acionistas que votaram a favor da inserção da cláusula compromissória estatutária, sendo a doutrina unânime quanto a esta vinculação.

\subsubsection{O acionista que ingressou na companhia após a inserção da cláusula}

Estão os acionistas que ingressaram na companhia após a inserção da convenção arbitral a ela vinculados? A questão suscita muita controvérsia entre os doutrinadores. A posição mais conservadora, defendida por Modesto Carvalhosa, entende que para que o novo acionista esteja vinculado ao pacto arbitral, deverá ele expressamente manifestar sua vontade em tal sentido. Defende esta corrente que é necessário a concordância através de documento apartado que seja encaminhado ao acionista pela companhia após a respectiva aquisição das ações, sob pena de, na ausência desta adesão específica, não estar o novo acionista vinculado à arbitragem. ${ }^{28}$

Segundo esta corrente doutrinária, que defende também que a vinculação à arbitragem se materializa através da renúncia da garantia do acesso à justiça ${ }^{29}$, esta vinculação seria possível apenas através da manifestação expressa e específica, não sendo admitida a aceitação tácita ou por referência. Defendem, portanto, que deverá o "novo acionista" da companhia, após subscrever as ações, aderir especificamente à cláusula arbitral, através de documento apartado e assinado.

Nas palavras de Modesto Carvalhosa:

"O pressuposto de validade e eficácia da decisão arbitral depende de expressa declaração de vontade das partes envolvidas, seja na cláusula compromissória, seja no compromisso propriamente dito. Há, com efeito, um requisito

\footnotetext{
${ }^{28}$ CANTIDIANO, Luiz Leonardo, Reforma da Lei das S/A. Rio de Janeiro: Renovar, 2002. 119 p.

${ }^{29}$ Cf. o Capítulo 1.2 deste trabalho.
} 
necessariamente de forma para a validade e eficácia da cláusula compromissória estatutária, que depende de sua específica e formal adoção por parte de todos os compromissados. Sem essa expressa aprovação, a cláusula compromissória é nula, por ferir o direito essencial do acionista de socorrer-se do Poder Judiciário. E essa aprovação vincula os fundadores na constituição e os acionistas que nas alterações estatutárias posteriores tiverem expressamente renunciado ao direito essencial prescrito no par. $2^{\circ}$ do art. 109 da Lei n. 6.404/76, para a inclusão desse pacto parassocial no estatuto." 30

Segundo este entendimento, seria necessária a formalização do consentimento mediante manifestação de vontade expressa ${ }^{31}$, na forma do art. $4^{\circ}$, par. $2^{\circ}$, da Lei de Arbitragem, através de uma analogia entre o estatuto social e os contratos de adesão. ${ }^{32}$ Pelo fato de que o acionista é parte mais fraca que a companhia e não tem a possibilidade de discutir as cláusulas do estatuto social, parte da doutrina considera que o art. $4^{\circ}$, par. $2^{\circ}$ da Lei 9.307/96 é aplicável. Portanto, a cláusula compromissória será oponível e produzirá efeitos em relação ao acionista apenas caso ele haja expressamente anuído aos seus termos.

\section{$\mathrm{O}$ doutrinador italiano Giorgio Bianchi possui o mesmo} entendimento de que o novo acionista não será parte na cláusula compromissória estatutária pelo simples fato de ter passado a integrar o quadro de acionistas, a não ser que, por escrito, em documento apartado revestido de todas as formalidades, tenha aderido ao pacto arbitral. ${ }^{33}$

Como a aquisição das ações se dá, em regra, através de mercado de balcão ou corretores, é provável que o novo acionista não tenha tomado conhecimento da cláusula arbitral constante do estatuto social. Por esta

\footnotetext{
${ }^{30}$ CARVALHOSA, Modesto e EIZIRIK, Nelson. Op. cit. p. 184-185.

${ }^{31}$ Segundo Modesto Carvalhosa: "não se impõe,portanto, erga omnes, a cláusula estatutária instituidora da arbitragem. Ela não vincula os acionistas que não tenham inequívoca, livre e expressamente contratado a referida cláusula ou a ela expressamente aderido, nos termos do par. $2^{\circ}$ do art. $4^{\circ}$ da Lei $n$. 9.307/96. Ibid, p. 202

${ }^{32}$ Art. $4^{\circ}$, par. $2^{\circ}$, Lei 9.307/1996: "Nos contratos de adesão, a cláusula compromissória só terá eficácia se o aderente tomar a iniciativa de instituir a arbitragem ou concordar, expressamente, com a sua instituição, desde que por escrito em documento anexo ou em negrito, com a assinatura ou visto especialmente para essa cláusula".

${ }^{33}$ BIANCHI, Giorgio. Questioni in materia di arbitraggio. 1999, p. 7. Apud CARVALHOSA, Modesto: "essas cautelas são necessárias para a certeza de que um ato tão importante como a renuncia à jurisdição ordinária seja realmente desejado por cada uma das partes."
} 
razão, e tendo em vista o princípio da autonomia da vontade, defende esta corrente que o novo acionista deve expressamente manifestar seu desejo de se vincular à arbitragem. Pelo fato do acesso à justiça se tratar de uma garantia constitucional, a derrogação da competência da autoridade judiciária só poderia ser validamente manifestada por escrito e por cada uma das partes que desejariam se vincular ao juízo arbitral, conforme estipulado em lei.

Apesar do grande respeito pelas opiniões dos notáveis doutrinadores, permitimo-nos discordar inteiramente deste entendimento. Primeiramente porque este entendimento é baseado no fato de que o estatuto social de uma companhia se assemelha a um contrato de adesão. Este entendimento não deverá prosperar e, desta maneira, o acionista não deverá ser equiparado a um consumidor hipossuficiente. ${ }^{34}$

O objetivo da legislação consumerista é proteger o consumidor, que é presumidamente hipossuficiente e a parte mais fraca da relação econômica. Por esta razão, inclusive, que a própria lei de arbitragem definiu que, para que a cláusula compromissória no contrato de adesão seja eficaz, é necessária a concordância expressa dos contratantes.

A natureza jurídica de ambos os institutos são diversas. Os estatutos sociais são caracterizados como contratos plurilaterais ${ }^{35}$, pois são diversas as partes contratantes, que buscam, em última instância, a mesma finalidade comum, que é o lucro e o desenvolvimento do empreendimento. A união dos esforços é que leva ao sucesso da companhia e, por esta razão, é que o

\footnotetext{
${ }^{34}$ Neste sentido: FLAKS, Luís Loria. A Arbitragem na Reforma da Lei das S/A. Revista de Direito Mercantil. $n^{\circ}$ 131. São Paulo: Malheiros, 2003. 102 p.

35 Neste sentido: ASCARELLI, Tullio. Problemas das Sociedades Anônimas e Direito Comparado. São Paulo: Saraiva, 1945. 271-272 p.; REQUIÃO Rubens, Curso de Direito Comercial. $28^{\mathrm{a}}$ Edição. São Paulo: Saraiva, 2011. 346 p.; PEDREIRA, José Luiz Bulhões. Natureza jurídica da companhia. Revista de Direito Renovar. $\mathrm{n}^{\circ}$ 12. Rio de Janeiro: Renovar, 1998. 105-120 p. e COMPARATO, Fábio Konder, Ensaios e Pareceres de Direito Empresarial. Rio de Janeiro: Forense, 1978. 137 p.
} 
interesse coletivo deverá prevalecer sobre os interesses individuais dos acionistas. Os contratos de adesão possuem, por sua vez, natureza bilateral, com cada parte buscando objetivos diversos, e é caracterizado pela reciprocidade de obrigações. Os estatutos sociais, conforme nos ensina Pedro Batista Martins, não podem ser equiparados aos contratos de adesão, justamente porque "é nas relações de consumo que se aperfeiçoam os contratos de adesão, contratos estes que divergem conceitual e instrumentalmente dos contratos de sociedade". ${ }^{36}$

Não obstante, mesmo considerada a hipótese de que os estatutos sociais podem, por analogia, serem considerados contratos de adesão, o dispositivo específico da lei de arbitragem não seria aplicável às sociedades anônimas. Pela regra de hermenêutica de interpretação legislativa, deve se levar em conta a lei posterior específica que trata da matéria que, neste caso, é a Lei 10.303/2001, que trata da arbitragem nas sociedades anônimas. O dispositivo incluído através da reforma da Lei das $\mathrm{S} / \mathrm{A}^{37}$ não determinou qualquer requisito formal para a vinculação da companhia e dos acionistas à cláusula arbitral, salvo a inserção da cláusula compromissória no estatuto da companhia. Seguindo este entendimento, concluímos que todos os acionistas que ingressaram na companhia posteriormente à inserção da cláusula arbitral estão a ela vinculados.

Por não se tratar de contrato de adesão, a manifestação de vontade do acionista pode se realizar de diferentes distintas. A legislação não previu, exceto no caso dos contratos de adesão, a forma sob a qual a manifestação de vontade de vincular-se à cláusula compromissória. A lei não exige, para

\footnotetext{
${ }^{36}$ MARTINS, Pedro Antonio Batista. A arbitragem nas sociedades de responsabilidade limitada. Revista de Direito Mercantil. $\mathrm{n}^{\circ}$ 126. São Paulo: Malheiros, 2002. p. 129.

${ }^{37}$ Art. 109, par. 3ํㅡㄴ Lei 6.404.1976, incluído pela Lei 10.303/2001: “O estatuto da sociedade pode estabelecer que as divergências entre os acionistas e a companhia, ou entre os acionistas controladores e os acionistas minoritários, poderão ser solucionadas mediante arbitragem, nos termos em que especificar".
} 
estes casos, a manifestação expressa por escrito como nos contratos de adesão.

A única exigência legal aplicável é a necessidade de que a cláusula compromissória seja convencionada por escrito ${ }^{38}$, requisito este que será sempre cumprido, pois a cláusula compromissória constará no estatuto social da companhia, que por sua vez deverá estar arquivado na Junta Comercial do Estado onde se localiza a sede da companhia.

Desta maneira, o ato de adquirir ações de uma companhia que possua o pacto arbitral em seu estatuto importará, consequentemente, na concordância com a referida cláusula compromissória, pois quem adquire ações está, ainda que por presunção, perfeitamente ciente de todos os termos e condições estatutários, dos quais não pode, posteriormente, pretender furtar-se. ${ }^{39}$

O novo acionista, ao adquirir as ações, deverá ter plena ciência dos termos do estatuto social da companhia em que está ingressando. Através da subscrição das ações, passará ele a incorrer em todos os direitos e obrigações ora decorrentes.

$\mathrm{Na}$ vida empresarial moderna, a manifestação de vontade, por vezes, se dá pela prática de determinados atos ou pela prática de certos comportamentos. Como se viu, a lei de arbitragem exige que a cláusula compromissória seja celebrada por escrito, para que se tenha a exata compreensão de sua extensão, mas nada determina a respeito de forma especial para a demonstração do consentimento das partes sobre aquela clausula escrita.

\footnotetext{
${ }^{38}$ Art. $4^{\circ}$, § 1 $1^{\circ}$, Lei 9.307/96: A cláusula compromissória deve ser estipulada por escrito, podendo estar inserta no próprio contrato ou em documento apartado que a ele se refira.

${ }^{39}$ MOREIRA, Daniela Bessone Barbosa. A Convenção Arbitral em Estatutos e Contratos Sociais. Arbitragem Interna e Internacional. Rio de Janeiro, São Paulo: Renovar, 2003. 374 p.
} 
Nelson Eizirik, que anteriormente defendia a necessidade, por parte do novo acionista da companhia, de ratificação expressa da cláusula compromissória estatutária, alterou seu entendimento neste ponto em artigo publicado no jornal Valor Econômico em 31 de agosto de $2009 .^{40}$ Eizirik passou a adotar o entendimento de que estes acionistas estão, a partir do momento em que subscrevem as ações, vinculados ao juízo arbitral. O fulcro desta mudança de entendimento restou justamente na conclusão de que o acionista, ao subscrever as ações, está ratificando e concordando com todos os termos do estatuto social. ${ }^{41}$

Por estas razões é que podemos concluir pela possibilidade da extensão dos efeitos da cláusula compromissória constante em estatuto social ao acionista não signatário, mas que, devido às circunstâncias específicas, manifestou sua vontade tácita ou indiretamente.

\subsubsection{O acionista ausente ou que se absteve de votar na assembleia}

A dúvida sobre a vinculação ou não do acionista à cláusula compromissória estatutária resta, inicialmente, na questão da manifestação da vontade. Isto porque o acionista, a princípio não teria manifestado sua vontade, nem contra e nem a favor, já que se absteve de votar ou esteve ausente da assembleia geral que reformou o estatuto social e incluiu o pacto arbitral.

Entendemos que neste caso houve manifestação de vontade tácita, pois o acionista, quando do seu ingresso na companhia, submeteu-se, voluntariamente, às suas regras corporativas. Assim, concordou não só com

\footnotetext{
40 EIZIRIK, Nelson. Quem se submete à arbitragem na S.A.? Disponível em: http://robertogentil.blogspot.com/2009/08/quem-se-submete-arbitragem-na-sa.html. Acesso em 02 de Maio, 2011
} 
as regras, mas como também, por exemplo, com os quóruns para alterar as disposições do estatuto e também com qualquer eventual posterior mudança operada pela maioria. A assembleia geral, quando agindo de forma legítima, representa os acionistas que a legitimaram. Caso tal reforma venha a ser operada pela assembleia, mesmo sem a participação do acionista, ela será válida e eficaz perante a ele.

No mesmo sentido a posição de José Virgílio Lopes Enei, in verbis:

"a decisão por maioria, portanto, não se dá à revelia do acionista dissidente, mas decorre de sua prévia e voluntária submissão às regras do jogo. É essa sua prévia e voluntária aceitação das regras corporativas que dá legitimidade à assembléia, conferindo-lhe poderes para deliberar em nome de todos os acionistas, e a todos vincular, ainda que por maioria de votos". ${ }^{42}$

Ressalte-se que, a bem da verdade, o Direito brasileiro admite que o consentimento ou a manifestação de vontade sejam expressos de forma tácita, demonstrados por outros meio que não a mera assinatura da parte. A esse respeito, o artigo 107 do Código Civil dispõe que "a validade da declaração de vontade não dependerá de forma especial, senão quando a lei expressamente exigir". Neste caso, a lei é específica em determinar que a cláusula arbitral deverá estar expressa por escrito. Não, há, porém, forma específica para a declaração de vontade de acionista para cláusula compromissória estatutária, tornando válida a deliberação da maioria em nome do acionista ausente ou que se absteve.

$\mathrm{O}$ art. 111 do Código Civil prevê, inclusive, que "o silêncio importa anuência, quando as circunstâncias ou os usos o autorizarem, e não for necessária a declaração de vontade expressa".

\footnotetext{
42 ENEI, José Virgílio Lopes. A Arbitragem nas Sociedades Anônimas. Revista de Direito
} Mercantil. $\mathrm{n}^{\circ}$ 129. São Paulo: Malheiros, 2003. 163 p. 
Vicente Raó esclarece esta possibilidade do consentimento através do silêncio no Direito Brasileiro:

"é incontestável e incontestado que o silêncio possui, na ordem jurídica, certo valor... Na realidade, o silêncio só produz efeitos jurídicos quando, devido às circunstâncias ou condições de fato que o cercam, a falta de resposta à interpelação, ato ou fatos alheios, ou seja, a abstenção, a atitude omissiva e voluntária de quem silencia induz a outra parte, como a qualquer pessoa 60 induziria, à crença legítima de haver o silente revelado, desse modo, uma vontade seguramente identificada." 43

Sobre a possibilidade do consentimento tácito na arbitragem, recorremos às lições de Pedro Batista Martins:

“o consentimento pode ser expresso ou tácito. (...) No âmbito da arbitragem, afirmam os estudiosos que o consentimento pode ser inferido, no caso concreto, por força de peculiaridades na atuação, postura, posição ou ação do terceiro frente ao negócio jurídico cujos termos e condições resultaram na disputa arbitral." ${ }^{, 44}$

Pode-se concluir que o Direito brasileiro admite, em tese, respeitadas as peculiaridades e particularidades de cada caso, que a manifestação de vontade que vincule uma pessoa a um procedimento arbitral seja demonstrada não só pela assinatura, mas também pela manifestação implícita, tácita ou indireta, manifestada por meio de atos e comportamentos característicos.

\subsection{5 $O$ acionista que dissentiu da inserção da cláusula}

A grande controvérsia do tema resta na divergência quanto à vinculação dos acionistas que votaram, em assembleia geral, contrariamente a inserção da cláusula compromissória estatutária.

\footnotetext{
${ }^{43}$ RÁO, Vicente. Ato Jurídico: noção, pressupostos, elementos essenciais e acidentais: o problema do conflito entre os elementos volitivos e a declaração. $4^{\mathrm{a}}$ Edição. São Paulo: Revista dos Tribunais, 1997. $426 \mathrm{p}$.

${ }_{44}$ MARTINS, Pedro Antonio Batista. Arbitragem. Capacidade, Consenso e Intervenção de Terceiros: Uma Sobrevista. Arbitragem Doméstica e Internacional. Estudos em Homenagem ao Prof. Theóphilo de Azeredo Santos. 1 ${ }^{a}$ Edição. Rio de Janeiro: Quartier Latin, 2008. 291-306 p.
} 
A doutrina, mais uma vez, possui entendimentos diametralmente opostos sobre o tema. A corrente mais conservadora defende que a cláusula compromissória não pode ser oponível aos acionistas que votaram contra a sua adoção no estatuto social. A segunda posição, que defende uma aplicação extensiva da cláusula compromissória, sustenta que todos os acionistas da companhia estariam vinculados à arbitragem, pois a vontade da maioria na assembleia geral exprime a vontade social de todos os acionistas.

Para a primeira corrente, os acionistas que não concordaram com a inclusão da cláusula compromissória de arbitragem não estariam a ela vinculados. Comentando esta situação, Luiz Leonardo Cantidiano assevera que:

"cabe indagar se as pessoas que já eram acionistas da companhia antes da realização da assembleia geral, e que se opuseram à referida alteração estatutária, estarão obrigadas a submeter-se ao procedimento arbitral", e que "a resposta a tal indagação me parece ser negativa; o acionista que vota contra não optou pela submissão de suas eventuais divergências à arbitragem, até mesmo porque inexistia previsão estatutária regulando a matéria."

Cantidiano conclui embasando seu entendimento no princípio da autonomia da vontade:

"considerando que ninguém pode ser obrigado a submeter-se, contra a sua vontade, ao processo arbitral, e tendo presente que o antigo acionista da companhia manifestou sua expressa divergência à reforma estatutária, entendo que a decisão adotada pela maioria não o obriga a aceitar a arbitragem, se requerida por terceiro (outro acionista ou a própria companhia)". 45

$\mathrm{Na}$ mesma linha de raciocínio, Modesto Carvalhosa defende que estão vinculados à arbitragem apenas e exclusivamente os acionistas que tenham expressamente concordado, através de manifestação formal da declaração de vontade, com a inserção da cláusula compromissória no

\footnotetext{
${ }^{45}$ CANTIDIANO, Luiz Leonardo, Reforma da Lei das S/A. Rio de Janeiro: Renovar, 2002. 320 p.
} 
estatuto $^{46}$. Esta manifestação formal das partes envolvidas no litígio seria pressuposto de validade e eficácia da sentença $\operatorname{arbitral}^{47}$.

Segundo esta linha de raciocínio, não há presunção de renúncia de direito essencial de qualquer acionista, pois não se poderia presumir que alguém delegou a competência a um juízo arbitral pela simples existência da cláusula compromissória estatutária e pelo fato de não pode haver renúncia implícita a um direito essencial do acionista.

Entendem ainda que pelo fato de a cláusula compromissória possuir natureza facultativa, não poderá ela ser oponível aos acionistas que não concordaram expressamente com sua inclusão, pois o estatuto não pode privar os acionistas do direito constitucional do acesso a justiça. Porém, como já tratado no capítulo anterior desta obra, a cláusula compromissória estatutária deriva justamente do exercício da garantia constitucional e não constitui óbice ao acesso à justiça. ${ }^{48}$

Sobre a necessidade de expressa aprovação do acionista, as palavras do mestre Carvalhosa:

\begin{abstract}
"há, com efeito, um requisito necessariamente de forma para a validade e eficácia da cláusula compromissória estatutária, que depende de sua específica e formal adoção por parte de todos os compromissados. Sem essa expressa aprovação, a cláusula compromissória é nula, por ferir o direito essencial do acionista de socorrer-se do Poder Judiciário". ${ }^{49}$
\end{abstract}

Nelson Eizirik, em seu artigo publicado no jornal Valor Econômico em 31 de agosto de 2008, apesar de ter mudado de opinião sobre alguns dos temas tratados neste trabalho, manteve sua posição no que diz respeito à não vinculação automática dos acionistas que expressamente discordarem da deliberação.

\footnotetext{
${ }^{46}$ CARVALHOSA, Modesto e EIZIRIK, Nelson. Op. cit. p. 196.

${ }^{47}$ MOREIRA, Daniela Bessone Barbosa. Op. cit. p. 367 - 368.

${ }^{48}$ Cf. Capítulo 1.2 deste trabalho.

${ }^{49}$ CARVALHOSA, Modesto e EIZIRIK, Nelson. Op. cit. p. 183.
} 
Eizirik considera que a cláusula compromissória possui natureza diversa das demais disposições do estatuto social e, por esta razão, ela não se aplica obrigatoriamente a todos os acionistas. Segundo Eizirik, na ponderação entre o princípio da autonomia da vontade, que legitima a arbitragem, e o princípio da maioria, que regula das sociedades anônimas, o primeiro prevalece e deverá ser estritamente observado. Por esta razão, os acionistas que votaram contra a inserção da cláusula compromissória estatutária não estão vinculados e não podem ser obrigados a participar da arbitragem.

A posição de Eizirik, in verbis:

"Vale observar que não se pode imputar à cláusula compromissória tratamento jurídico idêntico ao dispensado às outras cláusulas constantes do estatuto social, as quais impõem-se obrigatoriamente a todos os acionistas, mesmo os discordantes, gozando de caráter mandatório. Tendo em vista que a legitimidade da arbitragem repousa no princípio fundamental da autonomia da vontade, não se pode obrigar os acionistas que expressamente votaram contra a inclusão de cláusula compromissória no estatuto". 50

Ousamos, no entanto, discordar deste entendimento, pois o princípio da maioria rege a sociedade anônima na qual o acionista voluntariamente optou por ingressar e pelo fato de que a arbitragem, conforme demonstrado, constitui método eficaz de acesso a justiça, garantindo assim este direito constitucional. $^{51}$

A corrente doutrinária de vanguarda, a qual nos filiamos, defende que mesmo os acionistas que votaram contra a inserção da cláusula compromissória de arbitragem estariam vinculados aos seus termos. A decisão da maioria prevalece e vincula a todos os acionistas da companhia.

\footnotetext{
${ }^{50}$ EIZIRIK, Nelson. Op. cit.

${ }^{51}$ Cf. Capítulo 1.2 deste trabalho.
} 
A lei, de modo a proteger os direitos essenciais dos acionistas minoritários, previu, expressamente, as hipóteses que configuram abuso de poder da maioria. Estas hipóteses constituem exceções, e estão taxativamente previstas em lei. A lei não impôs, no caso específico de alteração estatutária para inserção de cláusula arbitral, qualquer condição especial para sua implementação que, inclusive, não origina direito de recesso por parte do acionista, pois estas hipóteses estão taxativamente previstas na legislação. ${ }^{52}$

Esta modificação não necessita de aprovação por quorum especial, salvo se de outro modo disposto no estatuto social, e não enseja direito de recesso. Logo, a modificação operada produzirá efeitos em relação a todos os acionistas, indistintamente. Não pode se cogitar nem da necessidade da unanimidade para a inserção da cláusula arbitral, já que a lei não previu este quorum especial, nem da vinculação de apenas parcela dos acionistas à arbitragem. Neste caso específico, o princípio da maioria deverá prevalecer, vinculando todos os acionistas às decisões da assembleia.

Todas as sociedades, principalmente as anônimas, são sustentadas e norteadas pelo principio da maioria. A regra da maioria é uma necessidade na disciplina das sociedades por ações. Neste sentido, Fabio Konder Comparato dispõe que seria totalmente desarrazoado aceitar a regra contratual do consentimento unânime nas deliberações sociais. ${ }^{53}$ No mesmo sentido dispõe Carvalho de Mendonça, para quem o critério da maioria deve ser adotado como uma necessidade lógica, pois exigir a unanimidade seria expor a sociedade à inação. ${ }^{54}$

\footnotetext{
${ }^{52}$ Neste sentido: MÜSSNICH, Francisco Antunes Maciel. Reflexões sobre o direito de recesso na Lei das Sociedades por Ações. Reforma da Lei das Sociedades Anônimas. Rio de Janeiro: Forense, 2002. 298 p.

${ }^{53}$ COMPARATO, Fabio Konder. O Poder de Controle na Sociedade Anônima. $4{ }^{\text {a }}$ Edição. Rio de Janeiro: Forense. 43-44 p.

${ }_{54}$ MENDONÇA, José Xavier Carvalho de. Tratado de Direito Comercial. $7^{\text {a }}$ Edição, Vol. IV, livro II, parte III. São Paulo: Freitas Bastos, 1945. 11 p.
} 
$\mathrm{O}$ direito da maioria de ditar as regras de funcionamento da sociedade busca a manutenção das atividades sociais, tendo em vista a necessidade de deliberações para alterar dispositivos de estatutos sociais que se tornaram desatualizados face à nova realidade comercial e econômica $^{55}$.

José Virgílio Lopes Enei, no sentido de que as decisões da assembleia devem ser observadas por todos os acionistas, in verbis:

"não cabe exigir, sob pena de se negar ao estatuto social o caráter de contrato organizativo, a aprovação expressa de todos os acionistas para a cláusula compromissória, até porque o acionista, ao ingressar na companhia, consente previamente, dentro dos limites da lei, com qualquer deliberação da assembleia, ainda que, ao tomar parte desta, reste vencido. $\mathrm{O}$ acionista não pode se escusar de cumprir o que foi deliberado pela assembleia apenas porque esta não teria sido a sua decisão pessoal". ${ }^{56}$

Pelas razões acima expostas, somos partidários da opinião de que os mesmo os acionistas que votaram contra a inserção da cláusula compromissória estão a ela vinculados.

\subsubsection{O acionista sem direito a voto ou com voto restrito}

As ações de uma companhia podem conferir ou não o direito de voto do acionista. ${ }^{57} \mathrm{O}$ acionista, ao subscrever as ações preferenciais sem direito a voto tem plena consciência de que não participará das decisões e deliberações da companhia, salvo se a lei ou o estatuto dispuser de maneira diversa. Desta maneira, o acionista, desde o momento em que subscreve as

\footnotetext{
${ }^{55}$ MARTINS, Pedro Antonio Batista. A arbitralidade subjetiva e a imperatividade dos direitos societários como pretenso fator impeditivo para a adoção da arbitragem nas sociedades anônimas. Disponível em http://www.batistamartins.com/artigos/arbsubimpdirsocprefatimpadoarbsocano.htm. Acesso em 08 de maio de 2011.

${ }^{56}$ ENEI, José Virgílio Lopes. Op. cit. 163.

${ }^{57}$ Art. 111, Lei das S/A: "O estatuto poderá deixar de conferir às ações preferenciais algum ou alguns dos direitos reconhecidos às ações ordinárias, inclusive o de voto, ou conferi-lo com restrições, observado o disposto no artigo 109."
} 
ações, se submete às deliberações que serão tomadas pelos demais acionistas, qualquer que seja seu conteúdo.

Deliberações importantes que envolvam, por exemplo, cisão, incorporação ou fusão da companhia, bem como a alteração de seu objeto social, dissolução da companhia, entre outras, serão tomadas independente da vontade dos acionistas detentores de ações preferenciais sem direito a voto. Por este motivo é que também não se levará em conta a vontade desses acionistas quando da deliberação assemblear que aprovar a alteração estatutária para prever a cláusula compromissória arbitral. ${ }^{58}$

O acionista poderá participar das assembléias, mas não poderá fazer valer a sua opinião ou vontade. Quaisquer deliberações, por mais importantes que sejam, serão tomadas independentemente da posição dos acionistas detentores de ações preferenciais. Por este motivo, e levando em consideração as posições e razões expostas ao longo deste trabalho, entendemos que os acionistas detentores de ações preferenciais sem direito a voto também estão vinculados à cláusula compromissória estatutária.

Sobre os acionistas detentores de ações preferenciais sem direito a voto, Nelson Eizirik defende que sua manifestação de vontade produzirá efeitos, devendo eles exprimirem sua vontade quando a inserção da cláusula compromissória de arbitragem. Seu voto não seria passível de contabilização para a aprovação ou não da inserção da cláusula, ou seja, não produziria efeitos em relação à companhia.

Porém, esta manifestação, segundo o autor, se faz necessária, pois aqueles que não se manifestaram na assembleia geral contrariamente à cláusula compromissória, ou a ela não compareceram, estarão vinculados ao compromisso arbitral. Ou seja, segundo Eizirik, mesmo os acionistas sem

\footnotetext{
${ }^{58}$ Neste sentido: FLAKS, Luís Loria. Op. cit. p.110.
} 
direito a voto poderiam se furtar ao compromisso arbitral, caso manifestem, no momento próprio, ser contra tal deliberação. ${ }^{59}$

Ousamos discordar inteiramente deste entendimento, justamente pelas razões previamente expostas e pelo fato de que o acionista não poderá dissentir do que foi deliberado pela maioria, principalmente neste caso, quando ele não possui direito a voto.

${ }^{59}$ EIZIRIK, Nelson. Op. cit. 


\section{Capítulo 3 \\ Limites Objetivos da Cláusula Compromissória de Arbitragem em Estatuto Social}

Outro tema de bastante complexidade é o que envolve o alcance objetivo da cláusula compromissória estatutária, ou seja, a definição de quais conflitos societários poderão ser solucionados através de arbitragem e a aplicação da cláusula arbitral no tempo.

José Virgílio Lopes Enei traz, a título de exemplo, uma relação de quais conflitos societários podem ser submetidos à apreciação do juízo arbitral: (i) interpretação do estatuto social ou dos demais documentos societários, (ii) interpretação da lei societária, exceto quanto às matérias de ordem pública, (iii) abusos por parte dos controladores, (iv) o exercício do direito de voto, do direito de preferência na compra de ações ou na integralização de capital, ou do direito de não ser diluído, (v) a distribuição de dividendos, (vi) o exercício do direito de retirada, inclusive no que diz respeito à aferição do valor econômico da sociedade, (vii) ofertas públicas, (viii) responsabilidade dos administradores e dos acionistas controladores, dentre outros. ${ }^{60}$ Nosso objetivo não é criar uma listar dos conflitos societários que seriam arbitráveis, mas sim analisar questões polêmicas que são objeto de reflexões pela doutrina.

\subsection{A Arbitragem Envolvendo Direitos Políticos do Acionista}

Deve a arbitragem societária se limitar as questões envolvendo direitos patrimoniais disponíveis? Dúvidas podem surgir devido a um aparente conflito entre art. $1^{\circ}$ da Lei de Arbitragem e o art. 109, par. $3^{\circ}$ da Lei das S/A. A Lei de Arbitragem dispõe no sentido de que apenas conflitos que envolvam direitos patrimoniais disponíveis poderão ser submetidos ao

\footnotetext{
${ }^{60}$ ENEI, José Virgílio Lopes. Op. cit. p. 168.
} 
juízo arbitral. Já a legislação societária, posterior à lei de arbitragem, se limita a dizer que a via arbitral poderá ser eleita para dirimir os conflitos entre os acionistas e a companhia, nos termos em que o estatuto social especificar. Não há menção a qualquer limitação da arbitragem a direitos patrimoniais. Por conta desta omissão surge a dúvida: poderão os conflitos relacionados a direitos de natureza política serem dirimidos através de arbitragem $?^{61}$ Os direitos de natureza política nas sociedades anônimas são aqueles que dizem respeito a direito de voto do acionista, seu direito de eleger membro de determinado conselho ou de votar em assembleia geral.

A Lei de Arbitragem utilizou a expressão direitos patrimoniais para definir a matéria que poderá ser objeto da arbitragem. Cumpre analisarmos se o direito de voto do acionista é um direito eminentemente político ou se ele possui um cunho patrimonial. Tendo em vista que o objetivo do acionista, ao ingressar no quadro social de uma companhia é, ao final, o desenvolvimento da companhia e a obtenção de lucro, concluímos que o direito de voto do acionista é um direito disponível que possui natureza patrimonial. Logo é perfeitamente possível a submissão destas questões que aparentemente envolvam direitos políticos do acionista à arbitragem, pois todas se originam de um direito patrimonial disponível do acionista.

\subsection{A Questão das Nulidades}

A teoria geral das nulidades, amplamente utilizada do direito civil, reza que não é permitido às partes nem ao juiz suprir as nulidades, pois os casos de nulidade envolvem questões de ordem pública e de direito indisponível da parte. Caso a aplicássemos à arbitragem societária, a conclusão necessária a que chegaríamos seria a de que apenas as questões

\footnotetext{
${ }^{61}$ MOREIRA, Daniela Bessone Barbosa. Op. cit. p. 374.
} 
envolvendo anulabilidade poderiam ser objeto de arbitragem, pois estas são as questões que comportam a renúncia, prescrição ou convalidação do ato. ${ }^{62}$

Deve-se observar, porém, a relação jurídica da qual surgiu a questão de direito indisponível a ser tratada. Caso ela tenha surgido de uma questão arbitrável, que envolva direitos patrimoniais disponíveis, o litígio e a questão em tese indisponível serão passíveis de análise pelo juízo arbitral. O direito indisponível tratado no caso terá natureza incidental, pois decorre do exercício de um direito disponível da parte, e assim poderá ser analisada pelo árbitro de modo a decidir a questão que lhe foi submetida.

Por estas razões, tem sido reconhecido, em sede doutrinária e jurisprudencial, que a teoria geral das nulidades não é totalmente aplicável à arbitragem societária. Portanto, a nulidade, nestes casos, é passível de convalidação, e assim já decidiu o Superior Tribunal de Justiça no Recurso Especial 35.230-0-Brasília, sob a relatoria do Ministro Sálvio de Figueiredo:

"Em face das peculiaridades de que se reveste a relação acionistas versus sociedade anônima, não há que se cogitar da aplicação, em toda a sua extensão, no âmbito do direito societário, da teoria geral das nulidades, tal como concebida pela doutrina e dogmática civilista. Em face disso, o direito de impugnar as deliberações tomadas em assembléia, mesmo aquelas contrárias à ordem legal ou estatutária, sujeita-se à prescrição, somente podendo ser exercido no exíguo prazo previsto na lei das Sociedades Anônimas. Pela mesma razão, não pode o juiz, de ofício, mesmo nos casos em que ainda não atingido o termo ad quem do lapso prescricional, reconhecer a ilegalidade da deliberação e declará-la nula." (grifos nossos)

Os ensinamentos de Erasmo Valladão Azevedo e Novaes França seguem esta mesma linha de raciocínio, na medida em que os autores

\footnotetext{
62 Art. 168. Código Civil: “As nulidades dos artigos antecedentes podem ser alegadas por qualquer interessado, ou pelo Ministério Público, quando lhe couber intervir. Parágrafo único. As nulidades devem ser pronunciadas pelo juiz, quando conhecer do negócio jurídico ou dos seus efeitos e as encontrar provadas, não lhe sendo permitido supri-las, ainda que a requerimento das partes."
} 
apontam diferenças entre o regime de invalidade aplicável ao direito civil em geral do regime aplicável às companhias, enumerando as seguintes diferenças:

$1^{\circ}$ ) prazos muito mais curtos de prescrição ou decadência (o que não significa que não haja casos de vícios imprescritíveis);

$\left.2^{\circ}\right)$ irretroatividade dos efeitos da invalidade, acarretando tão-somente a dissolução da companhia (em contraste com o que dispõe o art. 158 do Código Civil, que determina, primacialmente a restituição das partes ao status quo ante);

$3^{\circ}$ ) ampla possibilidade de sanação do vício, ainda que se trate, por vezes, de defeito que, segundo o direito comum, acarretaria a nulidade do ato (em contraste com o que determina o art. 146 do Código Civil, que veda a possibilidade de ratificação do ato nulo, mesmo que a requerimento das partes);

$4^{\circ}$ ) diverso enfoque da distinção entre atos nulos e anuláveis."

Seguindo esta linha de raciocínio, concluímos pela possibilidade de que o juízo arbitral analise e delibere sobre matérias que envolvam nulidades, desde que esta nulidade tenha surgido de uma questão que envolva direitos patrimoniais disponíveis das partes.

\subsection{Aplicação da Cláusula Compromissória Estatutária no Tempo}

Qual o juízo competente para julgar um conflito que se iniciou antes da inserção da cláusula arbitral? A quem deverá o acionista recorrer? A autoridade competente para julgar a demanda será o Tribunal Arbitral ou o Poder Judiciário?

Para tentar responder estas perguntas vamos recorrer às teorias de direito processual civil, que dispõe no sentido de que a nova regra

\footnotetext{
${ }^{63}$ AZEVEDO, Erasmo Valladão e FRANÇA, Novaes. Invalidade das Deliberações de Assembléia das S/Ai. São Paulo: Malheiros, 1999. 23 p.
} 
processual se aplica de imediato ${ }^{64} \mathrm{e}$, desta maneira, pode se entender que o juízo arbitral seria o competente para julgar uma disputa iniciada após a aprovação da cláusula arbitral, devendo esta nova disposição do estatuto ser respeitada e observada. Porém, por se tratar de uma situação especial e de extrema significância, a alteração da via judiciária pela via arbitral deve ser analisada com maior cautela.

José Virgílio Lopes Enei, citando a posição defendida pelo professor norte americano John Coffee, explica que, nesta situação, é mais correto entender que a cláusula arbitral recém adotada não deve retroagir para ser aplicada a conflitos relacionados com atos consumados anteriormente à sua adoção. Um dos motivos seria para evitar manobrar engendradas por acionistas controladores oportunistas, que poderiam inserir a cláusula arbitral quando assim lhe fosse conveniente.

A posição de John Coffee, in verbis:

"a further refinement on this question is wheatear any such substitution of remedies could apply retroactively with respect to causes of action that arose prior to the adoption of the charter provision (even if no suit was commenced). By analogy, Delaware's recent authorization of charter provisions limiting damages for due care liability applies only prospectively and does not limit the liability of a director for any act or omission occurring prior to the date when such provision becomes effective. (grifos nossos)"

O professor levanta a dúvida da possibilidade da utilização da arbitragem para a resolução de controvérsias iniciadas antes da adoção da arbitragem. Concordamos com estes entendimento, pois é necessário evitar que qualquer uma das partes se beneficiem desta mudança em detrimento da outra. Portanto às disposições da cláusula arbitral não poderão retroagir

\footnotetext{
${ }^{64}$ Neste sentido, Dinamarco: "a lei nova não atinge os atos processuais já praticados, nem seus efeitos, mas se aplica aos atos processuais a praticar, sem limitações relativas às chamadas fases processuais". DINAMARCO, Cândido Rangel et al.. Teoria geral do processo. $14^{\circ}$ Edição. São Paulo: Malheiros, 1998. 99 p.
} 
para governar fatos e conflitos ocorridos antes da sua inserção no estatuto social da companhia.

Esta questão envolvendo a aplicação intertemporal de cláusula arbitral pode vir a causar problemas no Brasil, particularmente no regulamento do Novo Mercado da BM\&F Bovespa, atualizado em 10 de maio de 2011, e que alterou a redação da cláusula arbitral vigente até então. Dedicaremos o próximo capítulo para tratar desta matéria. 


\section{Capítulo 4}

\section{A Câmara de Arbitragem do Novo Mercado da Bovespa}

O Novo Mercado da BM\&F Bovespa é um segmento especial de listagem da Bolsa de Valores de São Paulo desenvolvido com o objetivo de proporcionar um ambiente de negociação que estimule, ao mesmo tempo, o interesse dos investidores e a valorização das companhias. ${ }^{65}$

A adesão das companhias abertas ao Novo Mercado é voluntária e, através dela, as empresas se comprometem a adotar práticas de administração e governança corporativa mais rígidas e transparentes. Um das condições para a listagem no Novo Mercado é justamente a inserção da cláusula compromissória estatutária, conforme definido na Seção XIII do referido regulamento. A previsão da arbitragem é considerada um fator de segurança, atraindo assim os investidores.

A cláusula do regulamento do Novo Mercado, que estava em vigor até o dia 10 de maio de 2011, dispunha sobre arbitragem nos seguintes termos:

"13.1 Arbitragem. A BOVESPA, a Companhia, o Acionista Controlador, os Administradores e os membros do conselho fiscal da Companhia comprometemse a resolver toda e qualquer disputa ou controvérsia relacionada ou oriunda deste Regulamento de Listagem, do Contrato de Participação no Novo Mercado, das Cláusulas Compromissórias, em especial, quanto à sua aplicação, validade, eficácia, interpretação, violação e seus efeitos, por meio de arbitragem, perante a Câmara de Arbitragem, nos termos do seu Regulamento de Arbitragem."

A cláusula nestes termos, vinculava a Bovespa, a companhia, o acionista controlador, os administradores e os membros do conselho fiscal à arbitragem. É importante notar que os acionistas minoritários não estavam, portanto vinculados ao juízo arbitral na hipótese de controvérsias relacionadas às situações acima listadas.

\footnotetext{
${ }^{65}$ O Regulamento do Novo Mercado está disponível em: http://www.bmfbovespa.com.br/Pdf/RegulamentoNMercado.pdf. Acesso em 20 de Maio, 2011.
} 
Esta redação da cláusula arbitral foi elogiada ${ }^{66}$, na medida em que se afastou a dúvida de quais pessoas estariam vinculadas à arbitragem, pois as partes estão expressamente indicadas. Esta posição é perfeitamente compreensível, já que um dos objetivos da criação do Novo Mercado foi a de dar maior segurança ao acionista, estimulando assim o investimento.

Até então, pelo que tenho conhecimento, não havia grandes controvérsias doutrinárias em relação à redação da cláusula e às pessoas a ela vinculadas. O que pretendo levantar neste capítulo é um problema que pode vir a ser causado com a mudança da redação na cláusula arbitral constante na edição atualizada do regulamento do Novo Mercado, em vigor a partir de 10 de Maio de 2011. A nova cláusula arbitral passou a vigorar com a seguinte redação:

“13.1 Arbitragem. A BM\&F BOVESPA, a Companhia, o Acionista Controlador, os demais acionistas da Companhia, os Administradores e os membros do conselho fiscal da Companhia comprometem-se a resolver toda e qualquer disputa ou controvérsia relacionada com ou oriunda deste Regulamento de Listagem, do Contrato de Participação no Novo Mercado, do Regulamento de Sanções, das Cláusulas Compromissórias, em especial, quanto à sua aplicação, validade, eficácia, interpretação, violação e seus efeitos, por meio de arbitragem, perante a Câmara de Arbitragem do Mercado, nos termos do seu Regulamento de Arbitragem" (grifos nossos).

Detalhe para a mudança da redação da cláusula arbitral. Ela trouxe uma alteração importante, que foi a vinculação dos demais acionistas da companhia listada no Novo Mercado à arbitragem. A expressão demais acionistas engloba todos os acionistas da companhia. Portanto, como o acionista controlador já estava vinculado ao juízo arbitral, a mudança consiste no fato de vincular, a partir de agora, todos os acionistas minoritários de todas as companhias listadas no segmento do Novo Mercado.

\footnotetext{
${ }^{66}$ BARBOSA MOREIRA, Daniela Bessone. Op. cit. p. 389-390.
} 
Esta mudança é muito semelhante às situações descritas ao longo deste trabalho. Porém, há uma diferença significante neste caso específico, pois não se trata de deliberação assemblear que inseriu a cláusula no Estatuto da Companhia, o que, conforme visto, vincularia à todos os acionistas.

A primeira impressão é de que a BM\&F Bovespa está determinando unilateralmente, com esta mudança, que todos os acionistas resolvam suas eventuais disputas relacionadas aos temas descritos na cláusula acima transcrita segundo os termos por ela estipulados.

Mesmo levando em conta que estes acionistas estão vinculados à arbitragem em suas próprias companhias, já que a existência da cláusula arbitral é pressuposto da listagem no Novo Mercado, como devemos tratar a questão de que todos os acionistas destas companhias, até a entrada em vigor do novo regulamento, não estavam vinculados à arbitragem da Câmara de Arbitragem do Mercado para dirimir controvérsias relacionadas ao próprio regulamento, dentre outras questões, com a BM\&F Bovespa e com os demais entes mencionados na cláusula?

Não questionamos a situação dos investidores que adquirirem ações a partir de 10 de Maio de 2011, pois nos posicionamos no sentido de que estes acionistas estariam vinculados ao novo regulamento e à nova cláusula arbitral, pois devem estar cientes dela no momento da subscrição das ações. Acreditamos que a nova cláusula é válida no seu mérito, pois suas disposições, a partir do momento que entraram em vigor em diante, são perfeitamente válidas e eficazes. O problema resta no alcance subjetivo e intertemporal de seus efeitos.

$\mathrm{Na}$ ausência de um questionamento apurado, teremos a seguinte situação: a partir da entrada em vigor do novo regulamento, todos os 
acionistas que investem nas empresas do Novo Mercado passaram a ficar vinculados a uma cláusula arbitral a qual não anuíram expressamente.

Esta parece ser uma questão mais complicada do que as anteriormente analisadas pela doutrina envolvendo a vinculação de acionistas à arbitragem, pois não há, nem expressa nem tacitamente, uma manifestação de vontade do acionista em relação à cláusula arbitral. Também não há a manifestação de vontade de uma maioria à qual o acionista estaria obrigado a se submeter, como é o caso das sociedades anônimas. Trata-se de uma cláusula inserida unilateralmente no regulamento do órgão fiscalizador.

Para verificar se houve a manifestação de vontade, essencial para a vinculação à arbitragem, cumpre analisarmos o processo para modificação do regulamento que estava em vigor até 09/05/2010. Ele dispunha da seguinte maneira:

"14.2 Modificações. Qualquer modificação relevante a este Regulamento somente poderá ser levada a efeito pela BM\&FBOVESPA desde que:

(i) em Audiência Restrita realizada com as Companhias que tenham aderido ao Novo Mercado, em prazo fixado pelo Diretor Presidente, o qual não será inferior a 15 (quinze) dias, não haja manifestação contrária, expressa, superior a 1/3 (um terço) dos participantes da referida Audiência Restrita; e

(ii) a modificação tenha sido aprovada pela CVM."

A realização de uma audiência restrita, conforme mencionada acima, não pode ser considerada eficaz para vincular os acionistas da companhia. Primeiro pelo fato de que eles não tiveram ter tido conhecimento e possibilidade de participar da audiência, que, por sua natureza, foi restrita; não devem ter sido avisados desta mudança e, portanto não podem estar vinculados à cláusula arbitral. 
Caso se tratasse de uma assembleia geral da companhia aberta que reformasse o estatuto social e incluísse a cláusula compromissória, os acionistas teriam conhecimento da realização da assembleia e dos temas tratados, pois a convocação é feita mediante publicação em jornal. Todos os interessados teriam a oportunidade de votar contra ou a favor da inserção da cláusula, mesmo que, face ao princípio da maioria, os dissidentes fiquem vinculados à decisão majoritária. No caso da assembleia, os acionistas teriam conhecimento do fato e oportunidade de expressar seu voto. Poderiam, portanto, antes mesmo ou posteriormente a decisão, vender suas ações, por exemplo.

No caso da BM\&F Bovespa, a própria instituição decidiu realizar esta alteração, aparentemente sem a possibilidade do acionista minoritário, que a partir de agora pode estar vinculado à arbitragem, manifestar seu desejo de aderir à cláusula ou não. Neste caso, não há princípio da maioria que justifique esta vinculação, pois o investidor é acionista apenas da empresa, e não do órgão regulador.

Não há base legal ou principiológica que justifique esta vinculação compulsória à arbitragem, o que não é permitido pelo direito brasileiro. Enxergamos ser este um caso de arbitragem obrigatória, ferindo o princípio da autonomia da vontade e da garantia constitucional de acesso à justiça.

Por estes motivos consideramos esta parte da cláusula arbitral inconstitucional em relação aos antigos acionistas, especialmente em relação à litígios envolvendo situações ocorridas antes da entrada em vigor do novo regulamento.

Enxergamos neste caso a possibilidade da analogia do regulamento do Novo Mercado da BM\&F Bovespa aos contratos de adesão. Uma possível solução seria aplicar o par. $2^{\circ}$ do art. $4^{\circ}$ da Lei de Arbitragem. 
Assim, a nova cláusula arbitral só seria oponível aos demais acionistas caso estes expressamente, em documento apartado e por escrito, anuíssem aos termos da cláusula arbitral, ou se estes acionistas viessem a dar entrada no procedimento arbitral

O tema é novo e pode vir a suscitar posições divergentes. Uma possível posição liberal consideraria que a cláusula vincula a todos os participantes do Novo Mercado, pois as companhias, os acionistas e a própria bolsa são atores capazes e a matéria envolvida é de natureza disponível e passível de ser submetida à arbitragem. Também podem considerar impraticável a necessidade da anuência dos milhares de acionistas das companhias listadas no Novo Mercado.

Não pretendo esgotar o tema, mas apenas levantar esta preocupação de modo a suscitar o debate acadêmico sobre este ponto controverso. 


\section{CONCLUSÃO}

Procuramos, ao longo deste trabalho, analisar, a luz do princípio da autonomia da vontade na arbitragem, do princípio da maioria das sociedades anônimas e da garantia constitucional do acesso a justiça, os efeitos decorrentes da inserção de cláusula compromissória de arbitragem no estatuto social de uma sociedade anônima.

Diante de tudo que foi exposto, concluímos que os acionistas estão, em todas as hipóteses levantadas, vinculados à cláusula arbitral constante no estatuto social de sua companhia. Acionistas não devem ser equiparados a contratantes hipossuficientes e estatutos sociais não podem ser comparados a contratos de adesão, cogitando-se assim da aplicabilidade do art. $4^{\circ}$, par. $2^{\circ}$ da Lei de Arbitragem para reger questões envolvendo arbitragens societárias.

$\mathrm{O}$ acionista tem discernimento para investir no mercado de ações e deve estar sempre atento para as previsões e possibilidade de reforma do estatuto social da companhia da qual deseja se tornar acionista. Não poderá o ele arguir desconhecimento dos termos do estatuto social de modo a se resguardar e alegar não vinculação à cláusula arbitral estipulada.

Quanto às questões envolvendo os alcances subjetivos da cláusula, procuramos levantar questões controversas sugerindo o nosso ponto de vista, mas não pretendendo esgotar o assunto, que ainda carece de análise pela doutrina e pela jurisprudência.

O estudo de todos os temas tratados são de suma importância para a consolidação do desenvolvimento das companhias e da arbitragem, que tendem a caminhar cada vez mais juntas daqui para frente. 


\section{BIBLIOGRAFIA}

ALVIM, José Eduardo Carreira. Tratado Geral de Arbitragem. Belo Horizonte: Mandamentos, 2000. 144-145 p.

ASCARELLI, Tullio. Problemas das Sociedades Anônimas e Direito Comparado. São Paulo: Saraiva, 1945. 271-272 p.

AZEVEDO, Erasmo Valladão e FRANÇA, Novaes. Invalidade das Deliberações de Assembléia das S/Ai. São Paulo: Malheiros, 1999. 23 p.

BERTOLDI, Marcelo et al.. Reforma da Lei das Sociedades Anônimas Comentários à lei 10.303, de 31.10.2001. São Paulo: RT, 2002. 67 p.

CANTIDIANO, Luiz Leonardo, Reforma da Lei das S/A. Rio de Janeiro: Renovar, 2002. 119 p.

CARVALHOSA, Modesto e EIZIRIK, Nelson. A Nova Lei das S/A. São Paulo: Saraiva, 2002. 187 p.

COMPARATO, Fábio Konder, Ensaios e Pareceres de Direito Empresarial. Rio de Janeiro: Forense, 1978. 137 p.

Rio de Janeiro: Forense. 43-44 p.

DINAMARCO, Cândido Rangel et al.. Teoria geral do processo. $14^{\circ}$ Edição. São Paulo: Malheiros, 1998. 99 p.

ENEI, José Virgílio Lopes. A Arbitragem nas Sociedades Anônimas. Revista de Direito Mercantil. no 129. São Paulo: Malheiros, 2003. 163 p.

EIZIRIK, Nelson. Quem se submete à arbitragem na S.A.? Disponível em: http://robertogentil.blogspot.com/2009/08/quem-se-submete-arbitragem-nasa.html. Acesso em 02 de Maio, 2011.

FLAKS, Luís Loria. A Arbitragem na Reforma da Lei das S/A. Revista de Direito Mercantil. $\mathrm{n}^{\circ}$ 131. São Paulo: Malheiros, 2003. 102 p.

MAGALHÃES, Rodrigo Almeida. A Constitucionalidade da Arbitragem. Disponível em http://direito.newtonpaiva.br/revistadireito/docs/prof/13_prof_rodrigo5.pdf. Acesso em 10 de maio de 2011. 
MARTINS, Pedro Antonio Batista. Aspectos Fundamentais da Lei de Arbitragem. Rio de Janeiro: Forense, 1999. 1 p.

A arbitragem nas sociedades de responsabilidade limitada. Revista de Direito Mercantil. n 126. São Paulo: Malheiros, 2002. p. 129.

Arbitragem. Capacidade, Consenso e Intervenção de Terceiros: Uma Sobrevista. Arbitragem Doméstica e Internacional. Estudos em Homenagem ao Prof. Theóphilo de Azeredo Santos. $1^{\text {a }}$ Edição. Rio de Janeiro: Quartier Latin, 2008. 291-306 p.

A arbitralidade subjetiva e a imperatividade dos direitos societários como pretenso fator impeditivo para a adoção da arbitragem nas sociedades anônimas. Disponível em http://www.batistamartins.com/artigos/arbsubimpdirsocprefatimpadoarbsoc ano.htm. Acesso em 08 de maio de 2011.

MENDONÇA, José Xavier Carvalho de. Tratado de Direito Comercial. $7^{\mathrm{a}}$ Edição, Vol. IV, livro II, parte III. São Paulo: Freitas Bastos, 1945. 11 p.

MOREIRA, Daniela Bessone Barbosa. A Convenção Arbitral em Estatutos e Contratos Sociais. Arbitragem Interna e Internacional. Rio de Janeiro, São Paulo: Renovar, 2003. 374 p.

MÜSSNICH, Francisco Antunes Maciel. Reflexões sobre o direito de recesso na Lei das Sociedades por Ações. Reforma da Lei das Sociedades Anônimas. Rio de Janeiro: Forense, 2002. 298 p.

PEDREIRA, José Luiz Bulhões. Natureza jurídica da companhia. Revista de Direito Renovar. $\mathrm{n}^{\mathrm{o}}$ 12. Rio de Janeiro: Renovar, 1998. 105-120 p.

RÁO, Vicente. Ato Jurídico: noção, pressupostos, elementos essenciais e acidentais: o problema do conflito entre os elementos volitivos e a declaração. $4^{\mathrm{a}}$ Edição. São Paulo: Revista dos Tribunais, 1997. 426 p.

REQUIÃO Rubens, Curso de Direito Comercial. $28^{\mathrm{a}}$ Edição. São Paulo: Saraiva, 2011. 346 p. 